\title{
ARTIGO CIENTÍEICO \\ Tarifação para equacionar os serviços de saneamento ambiental, na cidade de Sousa, no Estado da Paraíba
}

\section{Pricing to equate environmental sanitation services, in the city of Sousa, in the State of Paraíba, Brazil}

\author{
Lilian Figueirôa de Assis ${ }^{* 1}$, Allan Sarmento Vieira ${ }^{2}$, Marcos Macri Olivera ${ }^{3}$
}

Resumo: O objetivo deste trabalho foi propor um método para calcular e equacionar as tarifas para os serviços de saneamento ambiental do Departamento de Água, Esgoto e Saneamento Ambiental (DAESA) da cidade de Sousa-PB, utilizando uma abordagem contábil-financeira. Adotou o método dedutivo, é classificada como exploratória, descritiva e do tipo documental, apresenta um estudo de caso e utilizou uma abordagem quantitativa. Com base nos dados apresentados pelo DAESA: consumo mensal, custos operacionais, número de ligações de abastecimento por tipo de usuário e ligações de esgotamento sanitário, entre outros, foi adotada uma análise considerando o custo-volume-lucro, referente à contabilidade de custos, de forma que essa metodologia pudesse fornecer base para atualização das tarifas existentes, por meio de correções percentuais sobre as mesmas. Para atender ao Ponto de equilíbrio econômico (PEE\$) calculado os valores deveriam ser ajustados em 74,9\%

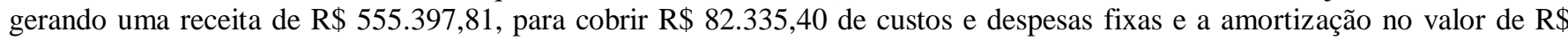
261.258,16, que foi o valor médio mensal da dívida, considerando os cinco últimos anos das faturas emitidas da Companhia de Água e Esgotos da Paraíba (CAGEPA) contra o DAESA. Por fim, descobriu-se ser necessário aproximadamente doze anos, transferindo esse valor amortizado, em parcelas iguais, para pagamento de água tratada pela CAGEPA. É importante afirmar que embora as limitações quanto à coleta das informações, há possibilidade de importar a proposta ao DAESA, corrigindo as atuais falhas quanto à sustentabilidade econômico-financeira.

Palavras-chave: Saneamento Básico; Tarifas; Cobrança.

\begin{abstract}
The objective of this work was to propose a method to calculate and equate the tariffs for the environmental sanitation services of the Department of Water, Sewage and Environmental Sanitation (DAESA) of the city of Sousa-PB, using an accounting-financial approach. It adopted the deductive method, is classified as exploratory, descriptive and documentary type, presents a case study and used a quantitative approach. Based on the data presented by DAESA: monthly consumption, operating costs, number of supply links by type of user and sewage connections, among others, an analysis was adopted considering cost-volume-profit, referring to cost accounting, so that this methodology could provide a basis for updating existing tariffs, by means of percentage corrections thereto. In order to meet the calculated Economic Break-Even Point (PEE $\$$ ), the amounts should be adjusted by $74.9 \%$, generating revenue of $\mathrm{R} \$ 555,397.81$, to cover $\mathrm{R} \$ 82,335.40$ of fixed costs and expenses and amortization of $\mathrm{R} \$ 261,258.16$, which was the average monthly value of the debt, considering the last five years of the invoices issued by Companhia de Água e egativos da Paraíba (CAGEPA) against DAESA. Finally, it was found to take approximately twelve years, transferring this amortized amount, in equal installments, to the payment of water treated by CAGEPA. It is important to state that, although the limitations on the collection of information, it is possible to import the proposal into the DESA, correcting the current flaws in economic-financial sustainability.
\end{abstract}

Key words: Basic sanitation; Tariffs; Collection.

\footnotetext{
*Autor para correspondência

Recebido para publicação em 28/11/2017; aprovado em 24/09/2018

${ }^{1}$ Especialista em Gestão Ambiental, Universidade Federal de Campina Grande, Sousa, Paraíba; Fone: (83)9-8111-6783, E-mail: assislilianf@ gmail.com.

${ }^{2}$ Doutor em Recursos Naturais, Universidade Federal de Campina Grande, allan.sarmento@ufcg.edu.br

${ }^{3}$ Mestre em Engenharia de produção, Universidade Federal de Campina Grande, macri.ccjs@ gmail.com
} 


\section{INTRODUÇÃO}

A preocupação com a recuperação, preservação e boa gestão dos recursos naturais está relacionado a condicionantes históricos. Ao longo dos anos o crescimento econômico tem sido considerado o responsável pela intensa exploração dos recursos naturais e acentuação dos problemas ambientais (POTT; ESTRELA, 2000; FREITAS, 2003; GOMES et al., 2003; JACOBI, 2005; VARGAS; MARCOS, 2005; MUCELIN; BELLINI, 2008; ZABALA; GARCIA, 2008; GIANNUZZO, 2010; PINTO; ZACARIAS, 2010; NETO; ROSA, 2012; SILVA; TRAVASSOS, 2012; FARIAS et al., 2013; MOTTA, 2013; GARRIDO CORDERO, 2016; IBANEZ; MUNOZ, 2017). Logo, a gestão ambiental pode ser entendida como um processo que busca a harmonização das interações entre as atividades humanas com a preservação dos ecossistemas ambientais (DULLEY, 2004; FERREIRA, 2005; MARTINS, 2011; SEIFFERT, 2011; OLIVEIRA, 2012; RAMOS; ATAIDE, 2013; HAMEL; GRUBBA, 2016).

Apesar da água ser considerada um recurso renovável, a degradação ambiental tem reduzido à capacidade de resiliência desse bem. Sendo necessária a utilização racional dos recursos hídricos, de tal forma que os mecanismos de gestão possibilitem à sustentabilidade (FREITAS, ORTIGARA, 2017; RIBEIRO, ROLIM, 2017). Assim, os modelos de gestão, a análise da oferta, o monitoramento das demandas e controle da qualidade das águas, entre outros, precisam ser adequadamente considerados (CAMPOS et al., 2014).

Embora haja ressalvas na definição de sustentabilidade, este conceito se refere ao desenvolvimento econômico viável, associado a uma atitude ou estratégia ecologicamente correta, socialmente justa e com uma diversificação cultural, de forma tal que garanta as futuras gerações o provimento de seu próprio bem estar (SERRANO; CARVALHO, 2013). No que diz respeito à água, seja ela recurso hídrico (águas superficiais e subterrâneas) ou serviços, que utilizam os recursos hídricos como matéria prima fundamental, em ambos os casos o conceito de sustentabilidade deve fundamentar os instrumentos de gestão desse bem (ROSS; PRETTE, 1998; PORTELA; BRAGA, 2006; TUNDISI, 2008; CAMPOS, 2013; MEDEIROS et al., 2013; BURITI; BARBOSA, 2014; CAVALCANTI; MARQUES, 2016; SERRER; SCHERER, 2016; SOUZA; SILVEIRA, 2016; FERREIRA et al., 2017; MORAIS et al., 2018). Nesse sentido, Müller et al. (2011) ressaltam a importância de relacionar uso eficiente e a preservação dos recursos hídricos aos princípios de desenvolvimento sustentável.

Segundo Leite e Vieira (2010) e Wolkmer e Pimmel (2013), o modelo de gestão dos recursos hídricos foi reformulado e iniciou-se uma nova fase com a aprovação da Lei Federal $n^{\circ}$ 9.433/97, que instituiu a Política Nacional de Recursos Hídricos (PNRH). Dessa forma, com intuito de alcançar os objetivos estabelecidos nesta Lei, foram instituídos cinco instrumentos de gestão: plano de recursos hídricos; enquadramento de corpos d'água; outorga de direito de uso; cobrança pelo uso da água; e sistema integrado de informação (DEMAJOROVIC et al., 2015).

Sendo a cobrança pelo uso da água indispensável não apenas para incentivar o uso racional, reduzir o lançamento de efluentes e valorizar o bem de uma forma geral, mas investir e recuperar a qualidade dos corpos hídricos procurando reverter, inclusive, o processo de degradação. Logo, a cobrança visa garantir aos múltiplos usos, o acesso à água (DIAS et al., 2010).

Santos (2012), ressalta a essencialidade deste instrumento, como uma forma de criar condições de equilíbrio entre disponibilidades e demandas, redistribuindo custos sociais e proporcionando a formação de fundos financeiros para manutenção da oferta hídrica, por meio de intervenções no setor (obras, programas e ações).

Outro marco foi a aprovação da Lei $\mathrm{n}^{\circ} 11.445$ (BRASIL, 2007; LEONETI et al., 2011; DUTRA, 2018), que estabeleceu as diretrizes nacionais para o saneamento ambiental, essa regulamentação compreende conjunto de quatro vertentes: as ações de abastecimento de água, esgotamento sanitário, manejo dos resíduos sólidos e manejo das águas pluviais (PEREIRA; HELLER, 2015). Vários autores discutem a importância desse serviços público à população (SCRIPTORE; TONETO JÚNIOR, 2012; CARUSO et al., 2014; ANTHONJ et al., 2016; ORTIZCORREA et al., 2016). Além de trazer responsabilidades para o ente municipal, com a implementação da política e elaboração do Plano Municipal de Saneamento Básico, trazendo dentro de seus princípios norteadores o controle social, a eficiência e sustentabilidade econômica, dentre outros (GALVÃO JUNIOR; PAGANINI, 2009; CARVALHO, 2015).

A inter-relação entre essas duas Políticas, como afirmado por Oliveira (2015), acompanha todo o processo que compreende desde a captação da água bruta até a disposição final nos corpos hídricos, caracterizando indissociabilidade ambiental. Faz-se necessário, portanto, que os instrumentos de natureza econômico-financeira ainda que tratados separadamente, sejam aproximados, como é o caso dos serviços de distribuição de água tratada, esgotamento sanitário, entre outros.

Apesar das limitações no que concerne a aproximação da proposta entre cobrança pelo uso da água e as tarifas de água e de esgoto, Serrano e Carvalho (2013, p. 330) mencionam estudos que comprovam que essa prática impulsiona inclusive a redução de perdas, ao se apoiar no mesmo princípio de racionalidade econômica sendo possível visualizar "efeitos sobre a postura do prestador de saneamento em relação ao lançamento de efluentes nos corpos hídrico".

A cobrança alicerça o desafio do gerenciamento sustentável das águas, impulsionando o uso racional (SERRANO; CARVALHO, 2013; MOTTA, 2013, SILVA, 2016). Ainda nesse sentido, Seiffert (2011) alerta que a utilização de um preço sobre o uso da água é mais do que um instrumento para gerar receitas para o Estado, é impulsora de mudanças comportamentais.

No caso das receitas oriundas dos serviços prestados pelos serviços de saneamento ambiental, diz a Lei $\mathrm{n}^{\circ}$ $11.445 / 2007$, que todo o recurso deve ser reinvestido para ampliação do acesso dos cidadãos, realização dos investimentos, estímulo ao uso de tecnologias modernas e eficientes e incentivo à eficiência, tudo objetivando o cumprimento das metas, continuidade e segurança na prestação dos serviços (BRASIL, 2007; COUTINHO, 2013; SERRANO; CARVALHO, 2013; ARRUDA et al, 2018; MELO; BRAGA, 2018). Em concordância com o disposto na Lei $\mathrm{n}^{\circ}$. 6.308/96, modificada pela Lei $\mathrm{n}^{\circ}$. 8.446/07, que instituiu no Estado da Paraíba, a cobrança pelo uso da água, também, determina que os recursos provenientes da cobrança 
devem ser aplicados para cobrir as despesas com a gestão, a operação e a manutenção das obras hídricas (PARAÍBA, 2007).

No município de Sousa, no Estado da Paraíba, a gestão de águas envolve três entes, o Departamento Nacional De Obras Contra as Secas (DNOCS), a Companhia de Água e Esgotos da Paraíba (CAGEPA) e o Departamento de Água, Esgotos e Saneamento Ambiental de Sousa (DAESA). O DAESA, autarquia criada, por meio da Lei Complementar $\mathrm{n}^{\circ}$ 31, de 4 de maio de 2004, é responsável pela arrecadação dos serviços de água referente às tarifas pela prestação dos serviços de abastecimento de água e coleta de esgotos. A cobrança é direcionada aos tipos de usuários: residenciais, industrial, pública e comercial e os valores foram regulamentados em 2009, sem atualizações anuais e com isenção da cobrança onde o consumo for inferior a $10 \mathrm{~m}^{3} \mathrm{de}$ água, dificultando assim a sustentabilidade econômicofinanceira desse ente (OLIVEIRA, 2015).

Contrariando a Lei $n^{\circ} 9.433 / 97$, a política pública de isenção de tarifas aplicada pelo DAESA, assim como a forma de gerenciamento deste programa, como apontado por Melo (2013), apresenta características únicas e que afrontam o que é preconizado nos princípios e fundamentos da Política Nacional de Recursos Hídricos.

Sendo assim, o desenvolvimento desta pesquisa, se justifica, já que água é recurso natural importante, do ponto de vista estratégico, no desenvolvimento de uma sociedade (FREITAS; ORTIGARA, 2017; MAIA, 2017; RIBEIRO; ROLIM, 2017) e pela intenção de propor uma metodologia de tarifas, que venha estimular a racionalização do bem, dando ao usuário uma indicação de seu real valor e promover a arrecadação de forma justa (lucros nulos), para obtenção de recursos financeiros para manutenção da oferta hídrica nesta cidade, beneficiando os usuários da água, além de assegurar uma boa gestão ao DAESA.

Partindo desse contexto, a cobrança dos recursos hídricos é um instrumento que visa o uso racional, a proteção e a preservação da água, assim como a cobrança pelos serviços de saneamento devem internalizar o conceito de sustentabilidade, o presente trabalho abre a discussão sobre a seguinte problematização: Como uma abordagem contábilfinanceira pode ser utilizada para auxiliar no cálculo das tarifas que cobram pelos serviços de saneamento ambiental, no Departamento de Água, Esgoto e Saneamento Ambiental (DAESA) na cidade de Sousa-PB?

Para tanto, inferiu-se como objetivo desta pesquisa propor um método para calcular e equalizar as tarifas para os serviços de saneamento ambiental do Departamento de Água, Esgoto e Saneamento Ambiental (DAESA) na cidade de Sousa, Paraíba.

\section{MATERIAL E MÉTODOS}

\section{Caracterização da área do estudo}

Sousa possui $814,71 \mathrm{~km}^{2}$, pertence à mesorregião do Sertão Paraibano e a microrregião de Sousa, com uma população estimada (2018) de 69.161 pessoas. População no último censo, 2010, era de 65.803 pessoas IBGE (2018). Segundo o Atlas (2016), a população cresceu entre 2000 e 2010 a uma taxa média anual de $0,56 \%$. A renda per capita média de Sousa cresceu 160,87\% nas últimas décadas, diminuindo assim a proporção de pessoas pobres e extremamente pobres, apesar disto ainda contém uma parcela da população em condições de vulnerabilidade no que diz respeito às questões relacionadas à água, ainda em 2010, os dados apontam que $85,22 \%$ da população residem em domicílios com banheiro e água encanada (ATLAS, 2016).

Localizada no semiárido nordestino brasileiro, no sertão do Estado da Paraíba, conforme Figura 01, a cidade de Sousa criou, em 2004, por meio de Lei complementar uma autarquia municipal para gerenciar os serviços de distribuição e tratamento da água - Departamento de Água, Esgotos e Saneamento Ambiental de Sousa (DAESA), que passou a atuar apenas em 2006, após disputar judicialmente com a Companhia de Água e Esgotos da Paraíba (CAGEPA), que realizava todo o processo de abastecimento de água e esgotos e cobrava por estes serviços (GADELHA, 2006). Apesar disto, a CAGEPA continua fazendo a captação, elevação, tratamento e armazenamento da água e o DAESA é responsável pela distribuição, manutenção das redes de água e esgotos em Sousa (MELO, 2013; OLIVEIRA, 2015).

Além disso, Sousa é abastecida pelo açude de São Gonçalo, reservatório com capacidade de 44,6 hm³ está atualmente com 25,8\% de sua capacidade (AESA, 2017), gerido pela autarquia federal Departamento Nacional De Obras Contra As Secas (DNOCS), inserido na bacia hidrográfica de Alto de Piranhas, sub-bacia do Rio Piranhas, que segundo Brasil (2016) tem a fruticultura irrigada como a principal atividade econômica da região, mas atende a outras demandas, tais como: consumos agroindustriais, domésticos, comerciais e públicos. Logo, a gestão de águas neste município envolve três entes, o DNOCS, a CAGEPA e o DAESA (MELO, 2013).

Figura 1. Localização da cidade de Sousa, Paraíba.

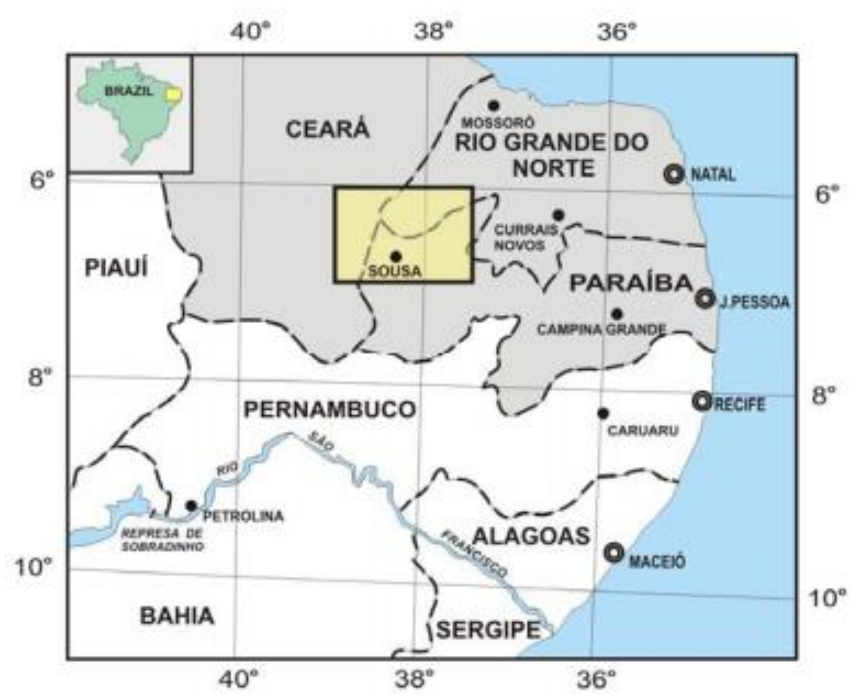

Fonte: Medeiros (2008).

Ainda nesse contexto de municipalização dos serviços de água na cidade, remontando o ano de 2004, a proposta político-partidária de criação do DAESA incluiu outro ator de interesse nessas questões, a população da cidade, incluindo nas decisões públicas uma maior participação da coletividade (empoderamento dos strakeholders), que por sua vez tinha como motivação uma política tarifária, isentando as famílias de baixa renda (MELO, 2013). 


\section{Tipo de pesquisa}

Esta pesquisa adotou como método de abordagem o dedutivo, fundamentado em premissas já estabelecidas, estrutura tarifária já disponível, comparação com a tarifa cobrada por outras concessionárias, assim como modelos matemáticos disponíveis na literatura, partindo do geral para propor algo particular, no caso, para o Departamento de Água, Esgoto e Saneamento Ambiental (DAESA).

Quanto aos fins, é do tipo exploratória e descritiva. Isso se deve ao fato de descrever o DAESA, objeto de estudo, explicitando as suas características, e exploratória porque, envolve pesquisa bibliográfica, estudo de caso e ainda estabelece relações entre variáveis, com a finalidade de proporcionar mais informações sobre a tarifação pelos serviços de saneamento ambiental.

Do ponto de vista dos procedimentos técnicos esta pesquisa é documental, esse delineamento é possível pela possibilidade de utilizar materiais que podem ser reelaborados de acordo com os objetivos da pesquisa, por meio de qualquer documento que possa ser usado como fonte de informação, por meio de investigação, que engloba: observação, leitura, reflexão e crítica (PRODANOV; FREITAS, 2013). É, também, um estudo de caso, por caracterizar em profundidade o DAESA.

No que se refere abordagem do problema, esta pesquisa é quantitativa, pois terá a pretensão de propor um método para o cálculo de tarifas, utilizando uma abordagem contábil, para (DAESA) na cidade de Sousa-PB e para isso utilizará bases para este cálculo matemático, nas estruturas tarifárias aplicadas por outras concessionárias e conceitos básicos de contabilidade de custos.

\section{Coleta de dados e análise dos resultados}

Foram realizadas entrevistas com o superintendente do DAESA, com o diretor administrativo-financeiro do DAESA e o sub Gerente da CAGEPA, seguindo um formulário semiestruturado que culminou em informações quantitativas.

Foram realizadas visitas as instituições nos meses de fevereiro e março de 2017 para apresentação do projeto de pesquisa, a fim de expor o objetivo e métodos do estudo, e para realizar as entrevistas. Apenas o diretor administrativofinanceiro do DAESA e o subgerente da CAGEPA se prontificaram em responder as perguntas, sem gravar, sendo as respostas anotadas no próprio formulário de entrevista.

A entrevista foi transcrita e, após a leitura cuidadosa de três trabalhos bases, a saber: MELO (2013), OLIVEIRA (2015) e GADELHA (2016), foram identificados tópicoschaves, que possibilitaram o agrupamento de temas, tal como orienta a Análise de Conteúdo Temática proposta por Minayo (2004), que consiste em descobrir os núcleos de sentido que compõem uma comunicação cuja presença ou frequência tenha significância para o objetivo analítico visado, na tentativa de diagnosticar a situação atual do DAESA.

Após esse levantamento foi possível, a partir das despesas apresentadas pelo DAESA, assim como outros dados verificados (consumo mensal, custos operacionais, número de ligações de abastecimento por tipo de usuário e ligações de esgotamento sanitário, entre outros), identificar uma metodologia, referente à contabilidade de custos, que pudesse fornecer base para atualização das tarifas existentes.

A análise da relação custo-volume-lucro foi base para esta proposta. A intenção é encontrar um valor de receita, que seja suficiente para se igualar aos gastos, nem gerando lucro, nem prejuízo, para a partir dessa técnica identificar quais as soluções para mudança de um cenário, se este estiver gerando prejuízo.

Hoji (2010) exemplifica esta base metodológica na literatura, para determinação do Ponto de Equilíbrio Contábil (PEC), conforme pode ser visualizado na Figura 2.

Figura 2. Ponto de equilíbrio contábil

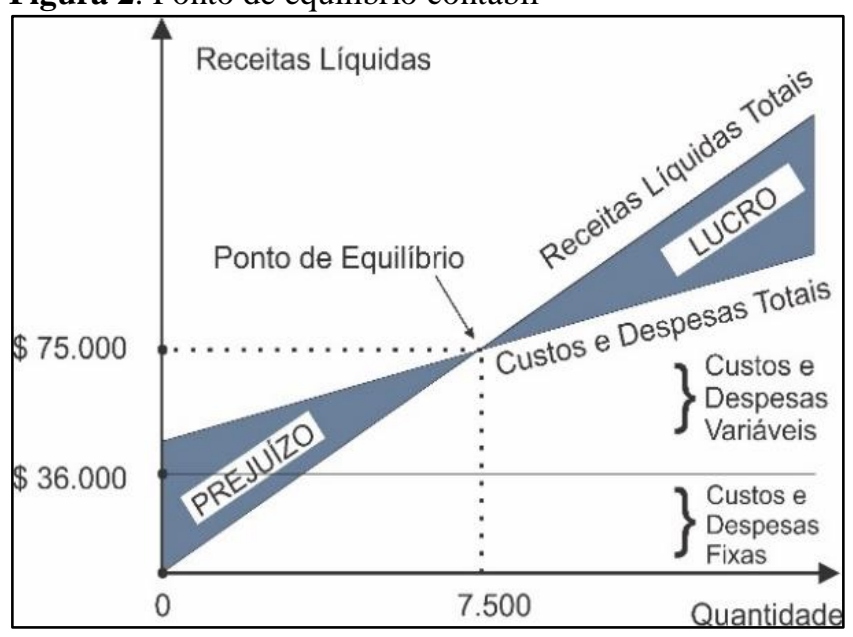

Fonte: Hoji (2010, p. 345)

Com base neste método e de posse dos dados do DAESA, foi possível determinar as correções percentuais sobre as tarifas cobradas atualmente de forma que alcançassem o valor de receita ideal (garantir o equilíbrio econômico e financeiro) e ainda sobrasse um valor para pagamento/negociação da "dívida" pela aquisição da água tratada e após a quitação reserva de "caixa" para investimentos vinculados a manutenção e ao desenvolvimento das políticas estabelecidas para o próprio setor.

O valor reservado para pagamento da dívida foi o valor médio "gasto" pela aquisição da água tratada, segundo as faturas que a CAGEPA emitiu cobrando o DAESA. Dessa forma, foi possível, a partir de um valor presente e os pagamentos em forma de parcelas mensais, descobrir o período de retorno (payback) e de quitação da dívida, que na teoria é utilizado para descobrir o tempo de recuperação de um investimento em um projeto, calculado a partir das entradas de caixa (GITMAN, 2010). Nesse caso, foi verificado em quanto tempo o DAESA consegue pagar as dívidas com a CAGEPA, a partir das saídas de caixa.

\section{RESULTADOS E DISCUSSÃO}

Tendo em vista de propor um método para equalizar e calcular as tarifas, utilizando uma abordagem contábilfinanceira para o Departamento de Água, Esgoto e Saneamento Ambiental (DAESA) na cidade de Sousa-PB, foi levantado informações financeiras e administrativas acerca do DAESA, identificado os potenciais metodológicas que atualizem o instrumento da cobrança atual e demonstrado como a metodologia escolhida pode atender o equilíbrio econômico e financeiro como a modicidade tarifária para o DAESA.

O Departamento de Águas, Esgotos e Saneamento Ambiental de Sousa - DAESA

O DAESA foi criado, em 2004, quando o Poder Legislativo municipal aprovou a Lei complementar $n^{\circ}$ 
031/2004 que instituiu esta autarquia, determinando dentre suas competências e atribuições o art. $4^{\circ}$, da referida Lei, visando atender a três objetivos: 1 - promover a captação, tratamento e distribuição de água tratada à população; 2 Promover a coleta e tratamento do esgotamento sanitário; e 3 - realizar os serviços de coleta, disposição final e reciclagem dos resíduos sólidos urbanos, ou seja, a gestão do saneamento ambiental. Além disso, compete a este órgão, também, realizar a gestão estratégica e buscar investimentos e estímulo à eficiência dos serviços por ele administrados. Em seu texto, estão entre as obrigações do DAESA, expostas no Quadro 1:

Quadro 1. Competências e atribuições do Departamento de Água, Esgoto e Saneamento Ambiental (DAESA) na cidade de Sousa, Paraíba

\begin{tabular}{|c|c|}
\hline I & $\begin{array}{l}\text { Produção de água tratada, através de captação } \\
\text { superficial; }\end{array}$ \\
\hline II & $\begin{array}{l}\text { Produção de água, através de captação } \\
\text { subterrânea; }\end{array}$ \\
\hline III & $\begin{array}{l}\text { Distribuição de água tratada, diretamente aos } \\
\text { usuários; }\end{array}$ \\
\hline IV & $\begin{array}{l}\text { Processamento de esgotamento } \text { sanitário } \\
\text { incluindo coleta, tratamento e destinação final dos } \\
\text { efluentes líquidos residenciais, comerciais, } \\
\text { industriais e públicos; }\end{array}$ \\
\hline $\mathrm{V}$ & $\begin{array}{l}\text { Gestão do Saneamento ambiental, da coleta e } \\
\text { tratamento dos resíduos sólidos; }\end{array}$ \\
\hline VI & Gestão da reciclagem do lixo produzido; \\
\hline VII & Gestão estratégica dos seus serviços; \\
\hline VIII & $\begin{array}{l}\text { Busca de investimento e estímulos à eficiência e a } \\
\text { eficácia no setor de água e esgotos e limpeza } \\
\text { pública através da parceria com outros setores, } \\
\text { público ou privado. }\end{array}$ \\
\hline
\end{tabular}

Fonte: Adaptado da Lei complementar $n{ }^{\circ} 031 / 2004$

Conforme observado, o DAESA executa apenas os serviços de distribuição da água tratada aos usuários/consumidores. A justificativa deste ente público a tal fato é de que ainda encontra-se tramitando a ação judicial que discute a reversão dos bens móveis e imóveis à o DAESA, o que inclui a estação de tratamento de água e o imóvel sede local da CAGEPA em Sousa, motivo pela qual a CAGEPA ainda cobra pelos serviços de captação e produção de água tratada e o Município de Sousa ainda encontra-se impedido de executa-los diretamente.

Desse modo, como identificado por Melo (2013) e Oliveira (2015, p. 75) esta autarquia, não executa todas as atribuições descritas no art. $4^{\circ}$ da Lei ${ }^{\circ}{ }^{\circ} 031 / 2004$, limitando as ações "ao abastecimento de água, a coleta de esgotos, a limpeza de fossas sépticas, aos serviços de manutenção nas redes, às solicitações de novas ligações de abastecimento e esgotamento, no atendimento aos clientes, aos esclarecimentos e orientações à comunidade em programas de rádio e na cobrança pela prestação dos serviços".

Apesar disso, a direção administrativo-financeiro do DAESA afirma que há preocupação, pelos gestores dessa autarquia quanto ao lançamento dos efluentes em local impróprio e existe um projeto de construção da Estação de Tratamento de Esgotos em andamento para onde deverão ser remetidos os esgotos coletados, obrigação que ainda não é executada pelo DAESA.

No tocante aos serviços de limpeza urbana e manejo dos resíduos sólidos, a direção administrativo-financeiro do
DAESA menciona uma parceria com a administração direta municipal e lamenta o fato de dispor os resíduos sólidos em um aterro privado, fato que encarece os custos da prestação do referido serviço, segundo suas falas.

O Quadro 2 expõe as competências administrativas do DAESA, definidas pelo artigo $5^{\circ}$ da Lei Complementar municipal $n^{\circ} 031 / 2004$ :

Quadro 2 - Competências administrativas do Departamento de Água, Esgoto e Saneamento Ambiental (DAESA) na cidade de Sousa, Paraíba.

\begin{tabular}{|l|l|}
\hline I & $\begin{array}{l}\text { Estudar, projetar e executar, diretamente ou } \\
\text { mediante contrato, com terceiros ou organizações } \\
\text { especializadas, as obras relativas à construção, } \\
\text { ampliação e remodelação dos sistemas públicos de } \\
\text { abastecimento de água e esgoto; }\end{array}$ \\
\hline II & $\begin{array}{l}\text { Estudar, projetar e executar a coleta dos resíduos } \\
\text { sólidos e os serviços de limpeza urbana; }\end{array}$ \\
\hline III & $\begin{array}{l}\text { Estudar, projetar e executar a construção do aterro } \\
\text { sanitário, unidades de compostagem ou reciclagem e } \\
\text { outras ações necessárias de saneamento ambiental; }\end{array}$ \\
\hline IV & $\begin{array}{l}\text { Atuar como órgão coordenador e fiscalizador dos } \\
\text { convênios entre o Município e órgãos Federais e } \\
\text { Estaduais, para estudos, projetos e obras de } \\
\text { construção, ampliação ou remodelação dos serviços } \\
\text { públicos de abastecimento de água, de esgotos } \\
\text { sanitários e saneamento ambiental; }\end{array}$ \\
\hline V & $\begin{array}{l}\text { Lançar, fiscalizar e arrecadar as contas dos serviços } \\
\text { de água, esgotos e coleta do lixo e as contribuições } \\
\text { de melhoria que incidirem sobre os terrenos } \\
\text { beneficiados com tais serviços; }\end{array}$ \\
\hline VII & $\begin{array}{l}\text { Fiscalizar os cursos de águas ou os mananciais do } \\
\text { município contra a poluição e sua exploração } \\
\text { inadequada, em parceria com a Agência Municipal } \\
\text { de Desenvolvimento de Sousa; }\end{array}$ \\
\hline VII & $\begin{array}{l}\text { Promover estudos e pesquisas de interesse para a } \\
\text { melhoria dos serviços de água, esgotos e saneamento } \\
\text { ambiental; } \\
\text { Promover às desapropriações dos bens necessários a } \\
\text { execução de seus serviços específicos; } \\
\text { Exercer quaisquer outras atividades relacionadas } \\
\text { com os sistemas municipais de água, esgotos e } \\
\text { vaneamento ambiental compatíveis com as leis em }\end{array}$ \\
\hline For.
\end{tabular}
Fonte: Adaptado da Lei complementar n ${ }^{\circ} 031 / 2004$

Com exceção das competências definidas nos incisos VI e VIII, todas demais atividades são exercidas exclusivamente pelo DAESA.

No que se refere à cobrança pelos serviços prestados, faz-se necessário citar a Lei $\mathrm{n}^{\mathrm{o}} 11.445$, de 5 de janeiro de 2007, quando menciona os aspectos econômicos e sociais em seu art. 29 dizendo que: "Os serviços públicos de saneamento básico terão a sustentabilidade econômico-financeira assegurada, sempre que possível, mediante remuneração pela cobrança dos serviços". Em conformidade no art. 11 da Lei municipal $n^{\circ}$ 031/2004 dispõe que a receita do DAESA será composta, dentre outras, pelas remunerações procedentes dos serviços de água e esgotos, tais como: instalações, reparos e aferição de hidrômetro, ligações de águas e esgotos, prolongamentos de redes, multas, entre outros. No entanto, fato identificado por Oliveira (2015), que persiste é que o DAESA se restringe a cobrar pelos serviços de abastecimento 
de água e coleta de esgotos, assim como, pela substituição de hidrômetros e ligações de abastecimento e esgoto.

Para tanto, o DAESA, como mencionado na introdução desse estudo, fato que justifica esta pesquisa, a estrutura tarifária deste ente foi regulamentada em 2009, não sendo atualizada desde então. Fato que contraria a Política Nacional de Saneamento Básico Lei $\mathrm{n}^{\circ} 11.445 / 2007$, que determina no Art. 37, que os reajustes de tarifas de serviços públicos de saneamento básico deverão ser realizados observando-se o intervalo mínimo de 12 (doze) meses, de acordo com as normas legais, regulamentares e contratuais. Apesar disto a direção administrativo-financeiro do DAESA, durante a entrevista, demonstrou inquietação para essa questão e ressaltou a importância de promover as revisões tarifárias anuais, para que haja equilíbrio econômico-financeiro e consequentemente melhorias nos serviços prestados.

De fato, se comparado aos demais indicadores de saneamento, a nível local, estadual, regional e nacional, como observado na Tabela 1, conforme dados catalogados, dos prestadores de serviços participantes, em 2015 e na média dos últimos 3 anos no Sistema Nacional de Informações Sobre Saneamento SNIS (2015), as tarifas cobradas em Sousa são inferiores as demais e o consumo médio por habitante dia é consideravelmente superior.

Tabela 1. Comparativo dos indicadores de saneamento 2015.

\begin{tabular}{ccc}
\hline & $\begin{array}{c}\text { Consumo médio } \\
\text { habitante/dia }\end{array}$ & $\begin{array}{c}\text { Tarifa } \\
\text { em R } \$\end{array}$ \\
\hline BRASIL & $165,3(1 /$ hab.dia $)$ & 2,96 \\
NORDESTE & 125,3 (1/hab.dia) & 3,02 \\
PARAÍBA & 136,7 (1/hab.dia) & 3,03 \\
DAESA & 189,5 (1/hab.dia) & 1,65 \\
\hline
\end{tabular}

Fonte: SNIS (2015)

Os preços cobrados pelos serviços de distribuição de água tratada e coleta de esgoto estão dispostos na Tabela 2, que resume as tarifas cobradas pelo DAESA. Percebe-se a ausência de taxas que especifiquem quanto é cobrado pelos demais serviços prestados pela autarquia, assim como faz a CAGEPA (verificar a tabela de serviços, multas, financiamentos e parcelamentos deste ente, disponível em site).

Percebe-se que a metodologia de cobrança está de acordo com a Lei $\mathrm{n}^{\mathrm{o}}$ 11.445/2007, que determina que a cobrança e deverá levar em consideração fatores, como as categorias de usuários, distribuída por faixas ou quantidades crescentes de utilização ou de consumo, entre outros.

Nesse sentido, os usuários/consumidores do DAESA encontram-se em quatro classes assim definidas: Residencial (R) - Residências, imóveis de moradia familiar; Comercial (C) - Comércio, imóveis que praticam atividade comercial de qualquer natureza; Industrial (I) - Indústria de pequeno, médio e grande porte existente na cidade; Público (P) Imóveis pertencentes ao poder público federal, estadual e municipal.

$\mathrm{Na}$ Tabela 3 observa-se um resumo da quantidade de imóveis cadastrados, conforme classificação dos usuários/consumidores do DAESA.
Tabela 2. Estrutura tarifária do Departamento de Água, Esgoto e Saneamento Ambiental (DAESA) na cidade de Sousa, Paraíba.

\begin{tabular}{|c|c|c|c|c|c|}
\hline $\begin{array}{c}\text { Categoria } \\
\text { de Consumo }\end{array}$ & $\begin{array}{l}\text { Tipo de } \\
\text { Tarifa }\end{array}$ & Água & Esgoto & $\begin{array}{c}\text { Esgot } \\
0 \\
(\%)\end{array}$ & $\begin{array}{c}\text { Água } \\
+ \\
\text { Esgot } \\
0\end{array}$ \\
\hline \multicolumn{6}{|l|}{ Consumo até } \\
\hline $10 \mathrm{~m}^{3}$ & Mínima & 14,22 & 2,3 & - & 16,52 \\
\hline 0 à $10 \mathrm{~m}^{3}$ & Normal & 14,22 & 5,69 & $40 \%$ & 19,91 \\
\hline 11 à $20 \mathrm{~m}^{3}$ & Normal & 1,83 & 0,73 & $40 \%$ & 2,56 \\
\hline 21 à 30 m $^{3}$ & Normal & 2,41 & 1,3 & $53 \%$ & 3,71 \\
\hline \multicolumn{6}{|l|}{ Acima de 30} \\
\hline $\mathrm{m}^{3}$ & Normal & 3,3 & 2,31 & $70 \%$ & 5,61 \\
\hline 0 à $10 \mathrm{~m}^{3}$ & Comercial & 25,39 & 10,16 & $40 \%$ & 35,55 \\
\hline \multicolumn{6}{|l|}{ Acima de 11} \\
\hline $\mathrm{m}^{3}$ & Comercial & 4,4 & 1,76 & $40 \%$ & 6,16 \\
\hline 0 à $10 \mathrm{~m}^{3}$ & Industrial & 30,75 & 12,3 & $40 \%$ & 43,05 \\
\hline \multicolumn{6}{|l|}{ Acima de 11} \\
\hline $\mathrm{m}^{3}$ & Industrial & 4,9 & 1,9 & $40 \%$ & 6,79 \\
\hline 0 à $10 \mathrm{~m}^{3}$ & Público & 28,83 & 11,53 & $40 \%$ & 40,36 \\
\hline \multicolumn{6}{|l|}{ Acima de 11} \\
\hline $\mathrm{m}^{3}$ & Público & 4,85 & 1,94 & $40 \%$ & 6,79 \\
\hline \multicolumn{6}{|c|}{$\begin{array}{l}\text { Fonte: Adaptado do DAESA, 2017. OBS.: Considera-se consumo não } \\
\text { medido até } 1 \mathrm{~m}^{3} \text {, nas economias com até } 03 \text { habitantes. }\end{array}$} \\
\hline \multicolumn{6}{|c|}{$\begin{array}{l}\text { Tabela 3. Número de Imóveis cadastrados servidos por água } \\
\text { na cidade de Sousa, Paraíba. }\end{array}$} \\
\hline \multicolumn{2}{|c|}{ Categorias } & $\begin{array}{l}\text { Túmero de } \\
\text { imóveis }\end{array}$ & \multicolumn{3}{|c|}{$\begin{array}{l}\text { Percentual de } \\
\text { imóveis }\end{array}$} \\
\hline \multicolumn{2}{|c|}{ Residencial } & 19.197 & \multicolumn{3}{|c|}{$95,20 \%$} \\
\hline \multicolumn{2}{|c|}{ Comercial } & 763 & \multicolumn{3}{|c|}{$3,78 \%$} \\
\hline \multicolumn{2}{|c|}{ Industrial } & 39 & \multicolumn{3}{|c|}{$0,19 \%$} \\
\hline \multirow{3}{*}{\multicolumn{2}{|c|}{$\begin{array}{l}\text { Público - Municipal } \\
\text { Público - Estadual } \\
\text { Público - Federal }\end{array}$}} & 107 & \multicolumn{3}{|c|}{$0,53 \%$} \\
\hline & & 37 & \multicolumn{3}{|c|}{$0,18 \%$} \\
\hline & & 21 & \multicolumn{3}{|c|}{$0,10 \%$} \\
\hline \multicolumn{2}{|c|}{ Publico - Federal } & 20.164 & \multicolumn{3}{|c|}{$100,00 \%$} \\
\hline
\end{tabular}

Fonte: DAESA, 2017

Dos imóveis residenciais, 18.447 são na zona urbana e 1.717 são na zona rural. Há de ser observado ainda que, em relação à classe de consumidores residenciais, esta encontrase subdividida em duas subclasses: consumidores de baixarenda (usuários inscritos nos programa Bolsa Família instituído pelo governo federal, com inscrição no NIS), cujo consumo mensal seja igual ou inferior a $10 \mathrm{~m}^{3}$ de água e consumidor residencial normal (demais consumidores não abrangidos na classificação anterior). Em relação às ligações de esgoto, apenas 6.409 são servidos por esgoto na zona urbana.

Deve ser ressaltado que à isenção de taxa, os consumidores devem estar cadastrados no programa social do Governo Federal de distribuição de renda, que apresentam o NIS (Número de Inscrição Social), com comprovação de renda de apenas um salário mínimo e consumindo no máximo $10 \mathrm{~m}^{3}$ de água.

O fato é que a Lei federal $n^{\circ} 11.445 / 2007$ determina que seja levado em considerado a possibilidade de subsídios tarifários e não tarifários e a Lei municipal no 031/2004 determina a conformidade com essa exigência, mas ocorre que dos 20.164 imóveis cadastrados, 3.546 usuários possuem cadastro no NIS, conforme a Figura 3, e são isentos de tais 
tributos, sem definição alguma, pela autarquia, de como serão obtidos os recursos para complementação das despesas. Neste aspecto cabe esclarecer que os atuais gestores do DAESA suspenderam totalmente novos cadastros de usuários de baixa-renda, com a justificativa de que será realizado um estudo de impacto financeiro, da isenção dos consumidores abrangidos pela tarifa social, para estabelecer normas de repasse da administração direta municipal para o DAESA do valor mensal dessas tarifas que não são recolhidas.

Figura 3. Usuários de água, da cidade de Sousa, cadastrados no NIS (Número de Identificação Social).

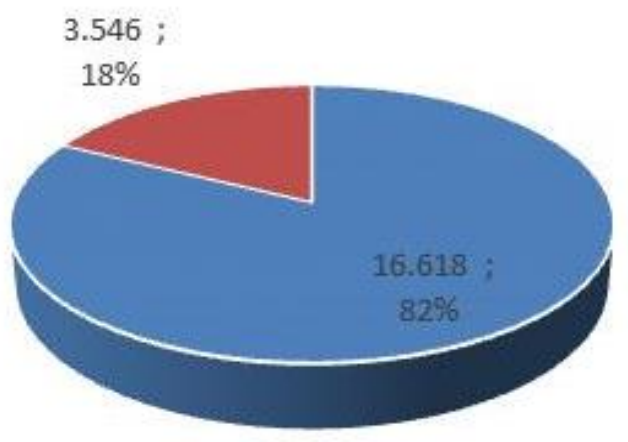

- Residenciais = NIS

Outra informação relevante é referente ao cadastro de imóveis sem a instalação de hidrômetros, dos 20.164 imóveis cadastrados, 2.725 não possuem hidrômetros, conforme Figura 04, o que impossibilita a mensuração real, acarretando em prejuízos econômicos e ambientais.

Um grupo de perguntas foi direcionado a composição dos custos e despesas do DAESA, houve certa dificuldade, por parte da direção administrativo-financeiro, para informar os valores, tendo em vista que a instituição possui natureza jurídica de autarquia, mas se configura, de forma anômala, como identificado por Melo (2013) e Oliveira (2015), atuando como um departamento submisso a administração pública municipal.

Apesar da determinação do Tribunal de Contas do Estado da Paraíba - TCE/PB, processo 15131/15, para a desvinculação do DAESA da administração direta do município, a partir de 2017, não foi possível verificar as demonstrações contábeis do período (janeiro e fevereiro de 2017), pois o DAESA ainda não funciona com autonomia administrativa e financeira, tendo sua contabilidade vinculada a administração direta municipal. Conforme observado, o DAESA continua sendo tratado como departamento vinculado à Secretaria de Infraestrutura municipal.
Figura 4. Hidrômetros instalados em imóveis, usuários de água, na cidade de Sousa.

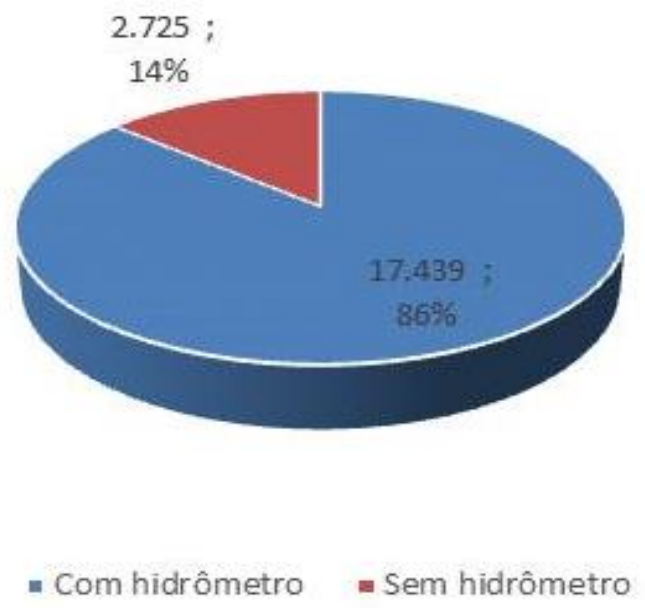

Mesmo assim, constatou-se a possibilidade do levantamento das informações necessárias para este estudo, detalhando, conforme perguntado um valor médio dos gastos.

Quando questionado sobre as despesas com imóvel, conforme afirmado inicialmente pela direção administrativofinanceiro do DAESA, há uma demanda judicial na qual o município de Sousa reivindica a reversão das instalações utilizadas pela CAGEPA para prestar os serviços que foram concedidos a sede administrativa regional local.

Como não houve decisão judicial definitiva em relação a tal pleito, razão pela qual a DAESA encontra-se impedida de assumir tais instalações imobiliárias, desde sua instituição e instalação no ano de 2006 até a data desta pesquisa o DAESA tem funcionado, em imóvel próprio da administração direta municipal ou em imóvel alugados. Atualmente sua sede administrativa encontra-se instalada em imóvel alugado ao custo mensal de $\mathrm{R} \$ 2.000,00$ (dois mil reais).

No que concerne os veículos automotores disponíveis ao DAESA, a autarquia conta apenas com 3(três) motocicletas próprias e 1(uma) motocicleta e 1 (uma) pick-up modelo Montana ambos cedidos pelos órgão da administração direta municipal.

Os demais veículos utilizados pelo DAESA na prestação dos serviços por ele executados são todos locados ao custo aproximado de $\mathrm{R} \$ 26.000,00$ (vinte e seis mil reais) sendo: 02 (dois) caminhões tanques com mecanismo de sucção e jateamento, ao preço unitário de $\mathrm{R} \$ 8.000,00$, totalizando o custo mensal de R \$ 16.000,00; 01 (uma caminhonete, modelo D-20, para transporte de servidores e de materiais aos locais de prestação de serviços, ao custo mensal de R\$ 2.500,00; 01(uma) retroescavadeira ao custo de $\mathrm{R} \$ 7.500,00$ mensal.

No que se refere às despesas diversas do órgão, com manutenção diversa, água, energia, telefone, internet, combustível, material de escritório (folhas, lápis, etc.), compra de material para prestação de serviços (quando a equipe é deslocada para o local para fazer serviço de saneamento ou manutenção da rede), o diretor informou um custo médio mensal aproximado de $\mathrm{R} \$ 10.000,00$ (dez mil reais).

Quanto aos custos e despesas com quadro de servidores do DAESA, a direção administrativo considera relevante esclarecer que, o quadro de pessoal, não possui nenhum servidor efetivo no seu quadro funcional, sendo esse 
composto por servidores comissionados e prestadores de serviços temporários.

Em relação aos valores dispendidos com servidores nos meses de janeiro e fevereiro de 2017, já que a direção administrativo-financeiro do DAESA só consegue responder pela gestão atual, por ter sido contratado recentemente e ainda não ter condições para responder pelos meses anteriores, há de ser destacado que a composição do quadro funcional tem atendido as necessidades emergenciais evitando-se gastos desnecessários.

Além disso, verificou-se uma incerteza destas informações, tendo em vista que os serviços de coleta, varrição e disposição final dos resíduos sólidos foram pagos pela administração direta, passado a ser quitados pelo DAESA a partir do mês de fevereiro/2017, que foi detalhada da seguinte forma: Servidores Comissionados - R\$ 16.525,00 (dezesseis mil, quinhentos e vinte e cinco reais) e servidores Contratados - R\$27.810,40 (Vinte e sete mil, oitocentos e dez reais e quarenta centavos).

Como os serviços de captação e tratamento de água bruta, ainda são exercidos pela CAGEPA, a DAESA, desde o início de suas atividades, adquire esse insumo ao custo de $\mathrm{R} \$$ 0,63 (sessenta e três centavos) por cada metro cúbico de água disponibilizada. Desde 2006, conforme exposto nos estudos de MELO (2013) e OLIVEIRA (2015), a CAGEPA vem repassando água tratada a o DAESA, conforme outorga de $159,44 \mathrm{l} / \mathrm{s}$, para que este último distribua para os usuários finais.

Essa condição acarreta em uma consequente dívida, calculada pela CAGEPA, totalizando um valor de aproximadamente $\mathrm{R} \$ 40$ mil (quarenta mil reais), conforme exposto na Figura 5. Porém o DAESA, afirma ser esta mais uma demanda judicial, tendo em vista que a autarquia reconhece a dívida, mas não formalmente, o diretor administrativo retomou a discussão do questionamento inicial, quanto as competências, reafirmando que a questão de captação e tratamento deveriam lhe ser restituída para possibilitar que a DAESA executasse diretamente tais serviços, ainda afirmam ter divergências quanto o volume de água tratada e fornecida mensalmente, já que não existia macromedição antes de janeiro de 2014, assim como questionam em relação ao preço do metros cúbico de água fornecida.

A direção administrativo-financeiro do DAESA acrescentou que a CAGEPA não recolhe o ISSQN sobre os serviços prestados ao DAESA e os órgão públicos estaduais também não pagam mensalmente as faturas decorrentes dos serviços de distribuição de água e coleta de esgotos que lhes são prestados pela DAESA, à exemplo de hospitais, colégios, órgão integrantes do sistema penitenciário, etc.

Em relação a inadimplência, é importante retomar aos dados dos números de imóveis cadastrados pelo DAESA e reconhecer que infelizmente dos 20.164 imóveis cadastrados e com a água ligada, apensas 19.115 pagam pelo consumo e 6.332, dos 6.409 imóveis servidos por esgoto são adimplentes com pagamento pelo serviço prestado. Essa problemática também foi mencionada nos trabalhos de Melo (2013) e Oliveira (2015) em que os mesmos descrevem as bases legais que respaldam tal prática. O Poder Executivo Municipal determinou proibido o corte no fornecimento de água ou energia elétrica por falta de pagamento no município de Sousa - PB, por meio da Lei $n^{\circ} 2.118 / 2007$. Fato este que agrava a saúde financeira do prestador dos serviços de saneamento básico neste município, o DAESA.

Figura 5. Faturas emitidas pela Companhia de Água e Esgotos da Paraíba (CAGEPA) cobradas ao Departamento de Água, Esgoto e Saneamento Ambiental (DAESA).

$\mathrm{R} \$ 6.000 .000,00$

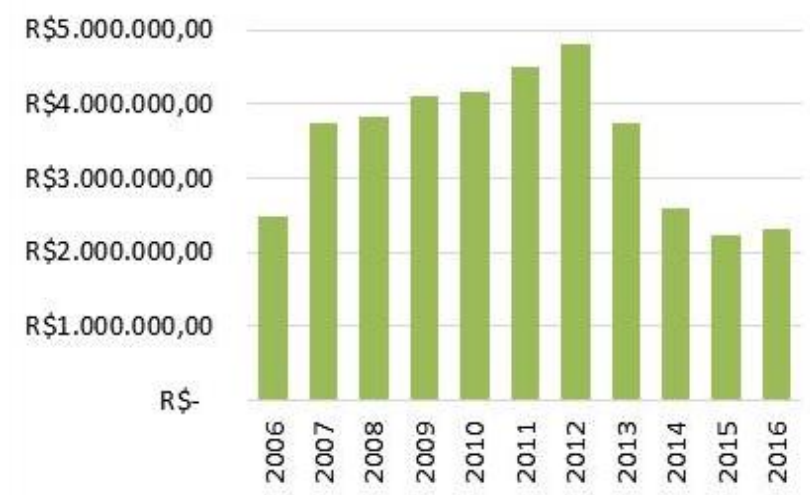

Fonte: Adaptado de CAGEPA (2017)

Após esse levantamento de informações sobre o DAESA, foi possível identificar elementos básicos da gestão desse órgão que podem ser corrigidos por uma metodologia simples, que foi a base desse estudo, a análise relação custovolume-lucro, determinação do ponto de equilíbrio e por fim uma proposta de ajuste nos valores regulamentos em 2009, levando em consideração a receita necessária para suprir os gastos desse órgão.

\section{Análise da relação custo-volume-lucro e correção das tarifas atuais}

As informações levantadas referentes aos gastos do DAESA precisam ser separadas em custos e despesas fixas e variáveis. Em virtude da incerteza das informações coletadas, pela ausência das demonstrações contábeis do setor, como explicado no tópico anterior, as despesas mencionadas serão todas apropriadas como custos e despesas fixas, exceto a aquisição do insumo água tratada, que determina aspecto variável, como um custo direto associado ao processo de distribuição da água. Posto isso a Tabela 4 demonstra o resumo das informações coletadas, no que se refere aos gastos.

Além disso, o preço de venda a ser utilizado na análise da relação custo-volume-lucro será o que apresenta maior frequência entre as receitas do DAESA, que são os imóveis residenciais, que consomem até 10 (dez) metros cúbicos. Sendo assim, se o consumidor paga $\mathrm{R} \$ 16,52$ até $10 \mathrm{~m}^{3}$ de água, já com a taxa do esgoto inclusa, significa que ele paga $\mathrm{R} \$ 1,65$ por cada metro cúbico de água. Logo, esse será o preço de venda unitário.

De acordo com as faturas emitidas pela CAGEPA, no último ano, o valor médio da dívida é de $\mathrm{R} \$ 193.353,74$ mensal, porém este valor vai variar a depender dos períodos de estiagem, racionamento, dentre outros fatores. Fato esse, que pode ser observado no trabalho de Melo (2013), onde o mesmo apresenta a relação das faturas emitidas pela CAGEPA contra o DAESA, em que diverge consideravelmente do que foi apresentado no ano de 2016, por exemplo, o ano de 2012, com emissão de notas fiscais, que totalizaram ao final do exercício o valor de $\mathrm{R} \$$ $4.802 .137,83$, pela aquisição de $7.622 .441 \mathrm{~m}^{3}$. Esse valor gera 
um custo mensal de $\mathrm{R} \$ 400.178,15$. Sendo assim, para o valor atribuído, na forma de lucro esperado, para pagamento dessa dívida, por meio da negociação e parcelamento seria em torno de $\mathrm{R} \$ 261.258,16$ valor médio mensal, dos últimos 5 anos.

Tabela 4. Dados para análise da relação custo-volume-lucro

\begin{tabular}{lr}
\hline Descrição & Valor \\
\hline Preço de venda unitário & $\mathrm{R} \$ 1,65$ \\
Custo e despesas variáveis & $\mathrm{R} \$ 0,63$ \\
unitários & \\
\hline
\end{tabular}

\begin{tabular}{lr}
\hline \multicolumn{2}{c}{ Custos e despesas fixas } \\
\hline Descrição & $\mathrm{R} \$ 2.000,00$ \\
\hline Aluguel do prédio & $\mathrm{R} \$ 26.000,00$ \\
Aluguel de veículos & \\
automotores & $\mathrm{R} \$ 44.335,40$ \\
Salários & $\mathrm{R} \$ 10.000,00$ \\
Despesas diversas & $\mathrm{R} \$ 82.335,40$ \\
Total dos custos fixos & $\mathrm{R} \$ 261.258,16$ \\
Valor da dívida com a & \\
CAGEPA à ser amortizada & \\
\hline
\end{tabular}

Vale ressaltar que, os dados foram coletados na entrevista com o diretor administrativo-financeiro do DAESA e que compõem apenas os gastos relacionados às funções executados por este setor, posto isso, esclarece quaisquer dúvidas que venham a surgir sobre a divergência destes com os dados disponibilizados pelo Tribunal de Contas do Estado da Paraíba, no portal Sagres (2017), de acordo com a Tabela 5 , visto que as despesas com saneamento são em torno de $\mathrm{R} \$$ 225 mil reais, conforme Figura 05, anteriormente mencionado.

Tabela 5. Despesa Orçamentária, anual, da Prefeitura Municipal de Sousa, para saneamento

\begin{tabular}{lrr}
\hline \multicolumn{3}{c}{ Despesas com saneamento } \\
\hline 2006 & $\mathrm{R} \$$ & $28.014,01$ \\
2007 & $\mathrm{R} \$$ & $3.708,00$ \\
2008 & $\mathrm{R} \$$ & $3.180,00$ \\
2009 & $\mathrm{R} \$$ & $1.818 .436,31$ \\
2010 & $\mathrm{R} \$$ & $2.584 .522,39$ \\
2011 & $\mathrm{R} \$$ & $5.496 .921,37$ \\
2013 & $\mathrm{R} \$$ & $2.254 .575,68$ \\
2014 & $\mathrm{R} \$$ & $2.624 .938,56$ \\
2015 & $\mathrm{R} \$$ & $2.370 .121,53$ \\
2016 & $\mathrm{R} \$$ & $3.218 .352,75$ \\
\end{tabular}

Fonte: SAGRES (2017)

De acordo com a margem de contribuição unitária, o volume médio consumido em Sousa, no último ano (2016) foi de $306.910,70 \mathrm{~m}^{3}$, comprovado por meio das faturas emitidas ao DAESA, pela CAGEPA, conforme Tabela 6.

$\mathrm{O}$ volume em metros cúbicos que aumenta de $306.910,70 \mathrm{~m}^{3}$ para $336.197,22 \mathrm{~m}^{3}$, pode ser justificado pela mensuração correta dos domicílios que não possuem hidrômetros, conforme identificado na pesquisa e novas ligações, já que foi mencionado, durante a entrevista, a ausência de fiscalização e possíveis ligações de abastecimento sem autorização/registro, assim como aumentar a cobertura da rede de esgotos e cobrar também por esses serviços.

Depois de achar o ponto de equilíbrio das contas, foi possível, atribuindo um percentual de ajuste sobre a estrutura tarifária atual, a atualização dos valores, de forma que o somatório dos números de imóveis que pagam multiplicados pelo novo valor fosse exatamente o valor do PEE\$.

Tabela 6. Faturas emitidas pela Companhia de Água e Esgotos da Paraíba (CAGEPA) contra o Departamento de Água, Esgoto e Saneamento Ambiental (DAESA).

\begin{tabular}{llrc}
\hline Ano & \multicolumn{2}{c}{ Valor da fatura } & Volume tratado \\
\hline Janeiro & $\mathrm{R} \$$ & $120.839,04$ & $191.808,00$ \\
Fevereiro & $\mathrm{R} \$$ & $112.674,24$ & $178.848,00$ \\
Março & $\mathrm{R} \$$ & $121.927,68$ & $193.536,00$ \\
Abril & $\mathrm{R} \$$ & $187.248,60$ & $297.220,00$ \\
Maio & $\mathrm{R} \$$ & $227.205,09$ & $360.643,00$ \\
Junho & $\mathrm{R} \$$ & $231.692,58$ & $367.766,00$ \\
Julho & $\mathrm{R} \$$ & $218.267,91$ & $346.457,00$ \\
Agosto & $\mathrm{R} \$$ & $213.226,02$ & $338.454,00$ \\
Setembro & $\mathrm{R} \$$ & $218.211,21$ & $346.367,00$ \\
Outubro & $\mathrm{R} \$$ & $228.132,79$ & $362.115,54$ \\
Novembro & $\mathrm{R} \$$ & $222.745,22$ & $353.563,84$ \\
Dezembro & $\mathrm{R} \$$ & $218.074,50$ & $346.150,00$ \\
\hline Total anual & $\mathrm{R} \$$ & $2.320 .244,88$ & $3.682 .928,38$ \\
Média mensal & $\mathrm{R} \$$ & $193.353,74$ & $306.910,70$ \\
\hline
\end{tabular}

Para isso, é preciso lembrar que dos 20.164 imóveis cadastrados servidos por água e dos 6.409 cadastrados e servidos por esgoto, $95,2 \%$ são residenciais, $3,8 \%$ são comerciais, $0,2 \%$ são industriais e $0,8 \%$ são públicos. Logo, se deste total, apenas $94,8 \%$ dos imóveis com água ligada pagam pelos serviços de abastecimento e $98,8 \%$ pagam pelos serviços de esgotamento, significa que 19.115 são os imóveis adimplentes no que se refere aos serviços de abastecimento e 6.332 são os de esgotos, distribuídos conforme exposto a seguir.

Tabela 7. Quantidade de usuários, por classificação, que pagam pelos serviços ao DAESA.

\begin{tabular}{lcc}
\hline Residencial & 18.198 & 6.028 \\
Comercial & 723 & 240 \\
Industrial & 37 & 12 \\
Público & 156 & 52 \\
\hline Total & 19.115 & 6.332 \\
\hline
\end{tabular}

Lembrando que, dos 18.198, apenas 6.028 residenciais não apresentam hidrômetro, que corresponde a 2.459 com água ligada e 815 com esgoto ligado, logo se enquadram na categoria de tarifa mínima, já o restante, 15.739 com água ligada e 5.214 com esgoto ligado pagam a tarifa da categoria normal. Sendo assim, se fosse considerado o consumo de todas as categorias de apenas $10 \mathrm{~m}^{3}$ mensal, o consumo mensal seria em torno de 191 mil metros cúbicos, gerando uma perda de aproximadamente $43 \%$ o que se explica pelas perdas no sistema de distribuição, segundo o SNIS (2015) o Nordeste apresenta um Índice de perdas na distribuição de 45,7\%. Logo, utilizando a estrutura tarifária do DAESA regulamentada em 2009, a receita seria de $\mathrm{R} \$ 317.512,88$, conforme demonstrado na tabela 8 .

Para atender ao PEE\$ calculado os valores deveriam ser ajustados em 74,921349\% gerando uma receita de $\mathrm{R} \$$ 555.397,81, conforme exposto na Tabela 9.

Esse ajuste resultaria na atualização da estrutura tarifária, apresentada na Tabela 10, conforme PEE\$ calculado. 
Tabela 8. Cobrança considerando a estrutura atual

\begin{tabular}{lcc} 
Pagam a tarifa & $\mathrm{R} \$ 34.971,99$ & $\mathrm{R} \$ 1.873,77$ \\
mínima (não medido) & $\mathrm{R} \$ 223.807,93$ & $\mathrm{R} \$ 29.665,71$ \\
Pagam tarifa normal & $\mathrm{R} \$ 18.364,74$ & $\mathrm{R} \$ 2.434,35$ \\
Comercial & $\mathrm{R} \$ 1.136,86$ & $\mathrm{R} \$ 150,64$ \\
Industrial & $\mathrm{R} \$ 4.509,48$ & $\mathrm{R} \$ 597,42$ \\
Público & $\mathrm{R} \$ 282.791,00$ & $\mathrm{R} \$ 34.721,88$ \\
Total & & \\
\hline
\end{tabular}

Tabela 9. Cobrança considerando o PEE\$.

\begin{tabular}{lcc}
\hline $\begin{array}{l}\text { Pagam a tarifa mínima } \\
\text { (não medido) }\end{array}$ & $\mathrm{R} \$ 61.173,48$ & $\mathrm{R} \$ 3.277,62$ \\
Pagam tarifa normal & $\mathrm{R} \$ 391.487,84$ & $\mathrm{R} \$ 51.891,66$ \\
Comercial & $\mathrm{R} \$ 32.123,86$ & $\mathrm{R} \$ 4.258,19$ \\
Industrial & $\mathrm{R} \$ 1.988,61$ & $\mathrm{R} \$ 263,50$ \\
Público & $\mathrm{R} \$ 7.888,04$ & $\mathrm{R} \$ 1.045,01$ \\
Total & $\mathrm{R} \$ 494.661,83$ & $\mathrm{R} \$ 60.735,97$ \\
\hline
\end{tabular}

Tabela 10. Proposta de atualização da estrutura tarifária.

\begin{tabular}{|c|c|c|c|c|c|}
\hline $\begin{array}{c}\text { Categoria } \\
\text { de Consumo }\end{array}$ & $\begin{array}{l}\text { Tipo de } \\
\text { Tarifa }\end{array}$ & Água & Esgoto & $\begin{array}{c}\text { Esgot } \\
0 \\
(\%)\end{array}$ & $\begin{array}{c}\text { Água } \\
+ \\
\text { Esgot } \\
0\end{array}$ \\
\hline \multicolumn{6}{|l|}{ Consumo até } \\
\hline $10 \mathrm{~m}^{3}$ & Mínima & 24,9 & 4,02 & - & 28,90 \\
\hline 0 à $10 \mathrm{~m}^{3}$ & Normal & 24,9 & 9,95 & $40 \%$ & 34,83 \\
\hline 11 à $20 \mathrm{~m}^{3}$ & Normal & 3,2 & 1,28 & $40 \%$ & 4,48 \\
\hline 21 à $30 \mathrm{~m}^{3}$ & Normal & 4,22 & 2,27 & $53 \%$ & 6,49 \\
\hline \multicolumn{6}{|l|}{ Acima de 30} \\
\hline $\mathrm{m}^{3}$ & Normal & 5,77 & 4,04 & $70 \%$ & 9,81 \\
\hline $\begin{array}{c}0 \text { à } 10 \mathrm{~m}^{3} \\
\text { Acima de } 11\end{array}$ & Comercial & 44,4 & 17,77 & $40 \%$ & 62,18 \\
\hline $\mathrm{m}^{3}$ & Comercial & 7,7 & 3,08 & $40 \%$ & 10,78 \\
\hline $\begin{array}{c}0 \text { à } 10 \mathrm{~m}^{3} \\
\text { Acima de } 11\end{array}$ & Industrial & 53,8 & 21,52 & $40 \%$ & 75,30 \\
\hline $\mathrm{m}^{3}$ & Industrial & 8,57 & 3,43 & $40 \%$ & 12 \\
\hline $\begin{array}{c}0 \text { à } 10 \mathrm{~m}^{3} \\
\text { Acima de } 11\end{array}$ & Público & 50,4 & 20,17 & $40 \%$ & 70,6 \\
\hline $\mathrm{m}^{3}$ & Público & 8,48 & 3,39 & $40 \%$ & 11,88 \\
\hline
\end{tabular}

Percebe-se que, mesmo com essa correção as tarifas ainda permanecem mais baixas do que as cobradas pela prestadora de serviços de saneamento do Estado da Paraíba (verificar a estrutura tarifária deste ente, disponível em site institucional), por exemplo, a CAGEPA cobra pela tarifa normal de abastecimento e esgotos até $10 \mathrm{~m}^{3}$ consumidos o valor de $\mathrm{R} \$ 66,31$, enquanto que para a proposta desse estudo esse valor ficou de $\mathrm{R} \$ 34,83$. O mesmo ocorre para as demais categorias: comercial, industrial e público, que para a mesma quantidade o valor é de $\mathrm{R} \$ 124,90, \mathrm{R} \$ 151,30$ e $\mathrm{R} \$ 149,32$, respectivamente, enquanto que a proposta sugeriu os valores de $\mathrm{R} \$ 62,18, \mathrm{R} \$ 75,30$ e $\mathrm{R} \$ 70,60$, respectivamente.

Outro detalhe é que a proposta foi direcionada a estrutura que o DAESA apresentou, embora existam outras fontes de receita que a autarquia não disponibilizou. Sobre isto a tabela de serviços, multas, financiamentos $\mathrm{e}$ parcelamentos, da CAGEPA, podem ser usados como modelo para o DAESA, fixando tarifas para os serviços que, inclusive, já são prestados pelo Departamento.

Além disso, podem aumentar a cobertura dos imóveis com esgoto ligado, realizando também o tratamento dos efluentes, já que atualmente só fazem a coleta e proporem novas tarifas para esses serviços, pois observa-se uma discrepância considerável entre as tarifas cobradas pela CAGEPA e pelo DAESA para estes serviços.

Por fim, é possível descobrir em quantos anos o DAESA conseguirá quitar a dívida, por meio de payback simples, que é de aproximadamente 12 anos, transferindo esse valor do lucro esperado para pagamento de água tratada pela CAGEPA.

A proposta utilizada possibilita a inserção da dívida, pela aquisição de água tratada, contraída pelo DAESA, ao passo que não realiza esta competência a ele conferida. Nesse sentido, é importante ressaltar que por disfunções da gestão dessa autarquia, o usuário final será "penalizado" se responsabilizando por essa conta, uma vez que a mesma foi adicionada ao cálculo, que resultou no reajuste da estrutura tarifária.

Outro ponto de destaque é o elevado percentual de reajuste, $74,921349 \%$, que poderia ser inferior se as correções tarifárias tivessem ocorrido anualmente, desde a sua regulamentação em 2009.

Pode-se sugerir que o DAESA, com precisão dos dados, possa refazer essa análise proposta, de modo que sejam levantadas todas as informações pertinentes para aplicação adequada da análise da relação custo-volume-lucro, visando à garantia de um serviço de qualidade e a sustentabilidade dos serviços.

Para isso, o DAESA precisará antes atender as demandas jurídicas no que se refere à adoção das medidas operacionais, formais e administrativas necessárias, com vistas a viabilizar a desvinculação do DAESA da administração direta do Município. Além disso, é preciso, efetivamente cobrar pelos serviços (todos os serviços prestados), adotar políticas de isenção, mas planejar receitas compensatórias para esses casos e estimular a criação/atuação da agência reguladora.

Além disso, é possível identificar outras abordagens que venham a auxiliar na decisão do preço de venda, neste estudo entendido como a cobrança pelos serviços. Metodologias que não só atualizem a estrutura atual, mas que busquem precificar os serviços.

\section{CONCLUSÕES}

A contabilidade é importante ferramenta de suporte à tomada de decisão dos gestores. Sendo que uma abordagem contábil pode ser utilizada para auxiliar no cálculo das tarifas. Uma dessas abordagens é a análise da relação custo-volumelucro sendo aplicada, a partir da análise das informações contábeis e assim determinando o ponto de equilíbrio como forma de ponto de partida para o ajuste na estrutura tarifária atual, com base nos custos relacionados pelo DAESA.

A inclusão do parcelamento da dívida com a CAGEPA, também é usual, porém, ainda não reconhecida formalmente, mas que se refere à aquisição de água tratada para posterior distribuição pelo Departamento. Logo, é possível estimar não apenas a receita necessária para cobrir os custos, mas considerar também possíveis amortizações ao modelo, por meio de um resultado positivo (lucro).

É importante afirmar que embora as limitações quanto à coleta das informações, há possibilidade de importar a proposta ao DAESA, de posse de todos os custos e despesas do setor é possível, encontrar a receita necessária para correta tomada de decisão dos gestores deste ente, incluindo as 
decisões sobre preço, corrigindo as atuais falhas quanto à sustentabilidade econômico-financeira, assegurando o equilíbrio econômico e financeiro e mantendo uma tarifa acessível para os cidadãos.

\section{REFERÊNCIAS}

ANTHONJ, C.; RECHENBURG, A.; KISTEMANN, T. Water, sanitation and hygiene in wetlands. A case study from the Ewaso Narok Swamp, Kenya. International Journal of Hygiene and Environmental Health, v. 219, n. 7, p. 606-616, 2016.

ARRUDA, P. N.; LIMA, A. S. C.; SCALIZE, P. S. Gestão dos serviços públicos de água e esgoto operados por municípios em Goiás, GO, Brasil. Ambiente, [S.L], v. 11, n. 2, p. 363-376, 2018.

ATLAS do desenvolvimento humano no Brasil. Disponível em:

<http://www.atlasbrasil.org.br/2013/pt/o_atlas/o_atlas_/>.

Acesso em 19 de outubro de 2016.

BRASIL. Lei n ${ }^{\circ} 11.445$ de 05 de Janeiro de 2007. Estabelece diretrizes nacionais para o saneamento básico. Disponível em: < htpp://www.planalto.gov.br/ccivil_03/_ato20072010/2007/lei/11445.htm > Acesso em: 24 de fevereiro de 2017.

BRASIL. Ministério das Cidades. Secretaria Nacional de Saneamento Ambiental. Sistema Nacional de Informações sobre Saneamento: Diagnóstico dos Serviços de Água e Esgotos - 2015. Brasília: SNSA/MCIDADES, 2017. 212 p.

BRASIL. Plano de recursos hídricos da bacia hidrográfica do rio Piancó-Piranhas-Açu. Agência Nacional de Águas. Brasília: ANA, 2016.

BURITI, C. de O.; BARBOSA, E. M. Políticas públicas de recursos hídricos no brasil: olhares sob uma perspectiva jurídica e histórico-ambiental. Veredas do Direito, Belo Horizonte, v. 11, n. 22, p. 225-254, 2014.

CAMPOS, M. V. C. V.; RIBEIRO, M. M. R.; VIEIRA, Z. M. C. L. A gestão de recursos hídricos subsidiada pelo uso de indicadores de sustentabilidade. Revista Brasileira de Recursos Hídricos. V. 19, n. 2, 2014.

CAMPOS, J. N. B. A gestão integrada dos recursos hídricos: uma perspectiva histórica. Revista Eletrônica de Gestão e Tecnologias Ambientais, [S.1.], v. 1, n. 1, p. 111-121, 2013.

CARUSO, B. A.; FREEMAN, M. C.; GAM, J. V.; DREIBELBIS, R.; SABOORI, S.; MUGA, R.; RHEIGANS, R. Assessing the impact of a school-based latrine cleaning and handwashing program on pupil absence in Nyanza Province, Kenya: a cluster-randomized trial. Tropical Medicine \& International Health, v. 19, n. 10, p. 1185-1197, 2014.

CARVALHO, A. V.. Educação ambiental no desenvolvimento sustentável municipal. Revista Interdisciplinar da Universidade Federal do Tocantins. v. 2 n. 01. p. 97-108, 2015.
CAVALCANTI, B. S.; MARQUES, G. R. G.. Recursos hídricos e gestão de conflitos: A bacia hidrográfica do rio Paraíba do Sul a partir da crise hídrica de 2014-2015. RGPLP, Lisboa, v. 15, n. 1, p. 04-16, 2016.

COUTINHO, D. R.. Saneamento básico: aumentos tarifários para investimentos na melhoria e expansão do serviço. RDA Revista de Direito Administrativo, Rio de Janeiro, v. 264, p. 281-300, 2013.

DEMAJOROVIC, J.; CARUSO, C.; JACOBI, P. R.. Cobrança do uso da água e comportamento dos usuários industriais na bacia hidrográfica do Piracicaba, Capivari e Jundiaí. Rev. Adm. Pública, Rio de Janeiro, v. 49, n.5, p.1193-1214, 2015.

DIAS, T. F.; BARROS, H. O. M.; SOUZA, W. J.. Cobrança pelo uso da água: visões a partir dos membros do comitê de bacia hidrográfica do Rio Pirapama - Pernambuco. Revista Alcance - Eletrônica. V. 17 - n. 4 - p. 416-432, 2010.

DULLEY, R. D. Noção de natureza, ambiente, meio ambiente, recursos ambientais e recursos naturais. Agric. São Paulo, São Paulo, v. 51, n. 2, p. 15-26, 2004.

DUTRA, A. R.. O papel dos municípios na implementação e fiscalização das disposições da política nacional de recursos hídricos em relação à perfuração de poços artesianos. Braz. J. of Develop., Curitiba, v. 4, n. 6, p. 3288-3297, 2018.

FARIAS, A. M. B.; MAZZARINO, J. M.; OLIVEIRA, E. C.. Educação ambiental e políticas públicas. Rev. Eletrônica Mestr. Educ. Ambient. v. 30, n. 1, p. 179 - 201, 2013.

FERREIRA, L. da C. Conflitos sociais e uso de recursos naturais: breves comentários sobre modelos teóricos e linhas de pesquisa. Política \& Sociedade, [S.L], n. 7, p. 105-118, 2005.

FERREIRA, F. N.; RIBEIRO, H. M. C.; BELTRÃO, N. E. S.; PONTES, A. N.; LOPES, S. R. M.. Gestão de recursos hídricos na Amazônia: um panorama da participação da sociedade civil nos espaços deliberativos. HOLOS, [S.L], v. 8, p. 336-351, 2017.

FREITAS, C. M. de. Problemas ambientais, saúde coletiva e ciências sociais. Ciênc. saúde coletiva, Rio de Janeiro, v. 8, n. 1, p. 137-150, 2003.

FREITAS, V. P.; ORTIGARA, R. J.. O Pagamento por Serviços Ambientais e a Preservação e Gestão de Recursos Hídricos no Estado do Paraná. Revista Argumentum - RA, eISSN 2359-6889, Marília/SP, V. 18, N. 3, pp. 645-663, 2017.

GADELHA, L. M. A ineficácia constitucional: o caso da municipalização dos serviços de água em Sousa (PB). Dissertação (Mestrado em gestão social e trabalho). Universidade de Brasília, Brasília, DF, 2006.

GALVÃO JUNIOR, A. C.; PAGANINI, W. S. Aspectos conceituais da regulação dos serviços de água e esgoto no Brasil. Engenharia Sanitária e Ambiental, v.14, n.1, p.7988, 2009.

GARRIDO CORDERO, Y. Programa de educación ambiental para la reducción de los problemas ambientales comunitarios. 
Estudios del Desarrollo Social, La Habana, v. 4, n. 1, p. 156-173, 2016.

GIANNUZZO, A. N. Los estudios sobre el ambiente y la ciencia ambiental. Sci. stud., São Paulo , v. 8, n. 1, p. 129156, 2010.

GITMAN, L. J.. Princípios de administração financeira. 12. ed. São Paulo: Pearson Prentice Hall, 2010.

GOMES, L. M. R.; SILVA, E.; RIBEIRO, G. A.; GRIFFITH, J. J.. Problemas Ambientais Causados pelo Ecoturismo no Setor Urbanizado do Subdistrito de Lavras Novas, Ouro Preto, MG. Turismo - Visão e Ação, [S.L], v. 5, n. 3, p. 239248, 2003.

HAMEL, E. H.; GRUBBA, L. S.. Desafios do desenvolvimento sustentável e os recursos naturais hídricos. Revista Brasileira de Direito, [S.L], v. 12, n. 1, p. 100-111, 2016.

HOJI, M.. Administração financeira e orçamentária: matemática financeira aplicada, estratégias financeiras, orçamento empresarial. 9. Ed. São Paulo: Atlas, 2010.

IBANEZ, M. E.; MUNOZ, L. V. A. La educacion ambiental como ámbito emergente de la educación social, un nuevo campo socioambiental global. RES - Revista de Educacion Social, [S.L], n. 25, p. 134-147, 2017.

IBGE. Instituto Brasileiro de Geografia e Estatística. 2010. Disponível em: <http://cidades.ibge.gov.br/xtras/perfil.php?lang\&codmun=25 1620\&search>. Acesso em 14 de nov de 2018.

JACOBI, P. Governança institucional de problemas ambientais. Política e Sociedade, [S.L], n. 7, p. 119-137, 2005

LEITE, G. B.; VIEIRA, W. C.. Proposta Metodológica de Cobrança pelo Uso dos Recursos Hídricos Usando o Valor de Shapley: Uma Aplicação à Bacia do Rio Paraíba do Sul. Est. econ., São Paulo, v. 40, n.3, p. 651-677, 2010.

LEONETI, A. B.; PRADO, E. L.; OLIVEIRA, S. V. W. B.. Saneamento básico no Brasil: considerações sobre investimentos e sustentabilidade para o século XXI. RAP Rio de Janeiro v. 45, n. 2. p. 331-48, 2011.

MAIA, I. L. B. O acesso à água potável como direito humano fundamental no direito brasileiro. Revista do CEPEJ, Salvador, vol. 20, pp 301-338, 2017

MARTINS, L. Gestão ambiental de recursos hídricos: pressupostos básicos, conceitos, modelos e instrumentos. Caminhos de Geografia, [S.1.], v. 11, n. 36, 2011.

MEDEIROS, V. C. de (Org.) Geologia e Recursos Minerais da Folha Sousa SB.24-X-A. Escala 1:250.000. Estados da Paraíba, Rio Grande do Norte e Ceará. / Vladimir Cruz de Medeiros...[et al.]. - Recife: CPRM - Serviço Geológico do Brasil, 2008.

MEDEIROS, J. de; GOMES, E. R. P.; BREY, N. K.; SOUZA, E. C. de; ROCHA, K. A.; TAQUES, J. G. A gestão de recursos hídricos - a água: um estudo em escolas na região do vale do Itapocu. Revista da UNIFEBE, [S.1.], v. 1, n. 12, 2013.
MELO, L. C. F. de; BRAGA, P. D. A remuneração dos serviços públicos de água e esgoto: taxa ou tarifa. Revista Jurídica UNIARAXÁ, Araxá, v. 17, n. 16, p. 127-148, 2018.

MELO, W. F.; Análise da Gestão da Demanda de Águas Superficiais No Município De Sousa-PB: O Caso DAESA (2006-2012). Dissertação (Mestrado em Sistemas Agroindustriais). UFCG, Centro de Ciências e Tecnologia Agroalimentar, Pombal, 2013.

MINAYO, M. C. S. O desafio do conhecimento: Pesquisa Qualitativa em Saúde. São Paulo - Rio de Janeiro: Hucitec: Abrasco, 2004.

MORAIS, J. L. M.; FADUL, É.; CERQUEIRA, L. S. Limites e desafios na gestão de recursos hídricos por comitês de bacias hidrográficas: um estudo nos estados do nordeste do brasil. READ. Rev. eletrôn. adm. (Porto Alegre), Porto Alegre, v. 24, n. 1, p. 238-264, 2018.

MOTTA, R. S.. Economia ambiental. 9. ed. Rio de Janeiro: Editora FGV, 2013.

MUCELIN, C. A.; BELLINI, M.. Lixo e impactos ambientais perceptíveis no ecossistema urbano. Sociedade \& Natureza, Uberlândia, v. 20, n. 1, p. 111-124, 2008.

MÜLLER, I. I.; RIZZI, N. E.; FILL, H. D. Avaliação da vazão indisponibilizada por usinas hidrelétricas em bacias hidrográficas e a cobrança pelo uso da água no setor hidrelétrico. Revista Floresta. Curitiba, v. 41, n. 4, p. 737750, 2011.

NETO, J. V.; ROSA, O. O estudo dos problemas ambientais urbanos através da geografia. Espaço em Revista, [S.1.], v. 12, n. 1, 2012.

OLIVEIRA, J. C. C. de. A política nacional de preservação e conservação do meio ambiente. Visão agrícola, [S.L], n. 10, p. 1-9, 2012.

OLIVEIRA, P. A.; A Municipalização dos Serviços de Saneamento: Uma Análise Jurídico-Hídrica do Gerenciamento em Sousa-PB, Adotado Pelo Departamento de Águas, Esgotos e Saneamento Ambiental - DAESA. Dissertação (Mestrado em Recursos Naturais) - Universidade Federal de Campina Grande, Centro de Tecnologia e Recursos Naturais, 2015.

ORTIZ-CORREA, J. S.; RESENDE FILHO, M.; DINAR, A. Impact of access to water and sanitation services on educational attainment. Water Resources and Economics, v. 14, p. 31-43, 2016.

PARAÍBA. Lei Estadual no ${ }^{\circ}$ 8.446. Dá nova redação e acrescenta dispositivos à Lei $n^{\circ}$. 6.308, de 02 de julho de 1996, que institui a Política Estadual de Recursos Hídricos, 2007.

PEREIRA, T. S. T.; HELlER, L.. Planos municipais de saneamento básico: avaliação de 18 casos brasileiros. Eng Sanit Ambient. v.20 n.3. p. 395-404, 2015.

PORTELA, N. F.; BRAGA, T. M. Conflitos federativos em gestão de recursos hídricos no Brasil: reflexões a partir do 
caso da bacia do rio Macaé (RJ). Geografias, Belo Horizonte, v. 2, n. 2, p. 74-85, 2006.

POTT, C. M.; ESTRELA, C. C. Histórico ambiental: desastres ambientais e o despertar de um novo pensamento. Estud. av., São Paulo, v. 31, n. 89, p. 271-283, 2017.

PRODANOV, C. C.; FREITAS, E. C.. Metodologia do trabalho científico [recurso eletrônico]: métodos e técnicas da pesquisa e do trabalho acadêmico. 2. ed. - Novo Hamburgo: Feevale, 2013.

RAMOS, M. H. R.; ATAIDE, S. G. de. Luta pela preservação ambiental: dilemas e contradições. R. Katál, Florianópolis, v. 16, n. 2, p. 186-195, 2013.

RIBEIRO, L. G. G.; ROLIM, N. D.. Planeta água de quem e para quem: uma análise da água doce como direito fundamental e sua valoração mercadológica. Revista Direito Ambiental e sociedade, v. 7, n. 1, p. 7-33, 2017.

ROSS, J. L. S.; PRETTE, M. E. D. Recursos hídricos e as bacias hidrográficas: âncoras do planejamento e gestão ambiental. Revista Do Departamento De Geografia, [S.L], v. 12, p. 89-121, 1998.

ROTH, E. Psicología ambiental: interfase entre conducta y naturaleza. Rev Cien Cult, La Paz, n. 8, p. 63-78, 2000.

SANTOS, A. H. L.. Política de cobrança de água: análise comparativa entre as metodologias de diferentes bacias hidrográficas do sudeste e do nordeste brasileiro. Revista Científica da Faculdade Darcy Ribeiro, nº 003, 2012.

SCRIPTORE, J. S.; TONETO JÚNIOR, R. A estrutura de provisão dos serviços de saneamento básico no Brasil: uma análise comparativa do desempenho dos provedores públicos e privados. Revista de Administração Pública. Rio de Janeiro, v.46, n.6, p.1479-1504, 2012.

SERRANO, L. M.; CARVALHO, M. V.. Cobrança pelo uso de recursos hídricos e tarifas de água e de esgoto: uma proposta de aproximação. REV. UFMG, Belo Horizonte, v. 20, n.2, p. 306-333, 2013.

SERRER, F.; SCHERER, M. P. O sistema brasileiro de gerenciamento dos recursos hídricos: Uma Proposta Democrática e Participativa no Tratamento da Água. Direito em Debate, [S.L], n. 45, p. 209-228, 2016.

SEIFFERT, M. E. B. Gestão ambiental: instrumentos, esferas de ação e educação ambiental. 2. ed. São Paulo: Atlas, 2011.

SILVA, T. S. Direito fundamental de acesso à agua potável: o fornecimento de água e a hipótese de suspensão por inadimplemento do usuário do Artigo 40, v, da Lei 11.445/2007 - Lei de Saneamento Básico. rev idea. v. 7, n. 2, P 1-32, 2016.

SILVA, L. S; TRAVASSOS, L. Problemas ambientais urbanos: desafios para a elaboração de políticas públicas integradas. Cadernos Metrópole., [S.1.], n. 19, 2012.

SOUSA. Lei Complementar $n^{\circ}$ 031/2004. Dispõe sobre os serviços públicos de água e esgoto no tocante a retomada da gestão e operação destes serviços pela Administração Municipal, cria o -Departamento de Água, Esgotos e
Saneamento Ambiental de Sousall - DAESA, e dá outras providências. Disponível em: < http://www.camarasousa.pb.gov.br/documentos/Leis_Comple mentares/2004/LCMn031-2004.pdf>. Acesso em: 24 de fevereiro de 2017.

SOUSA. Lei Municipal $n^{\circ}$ 2.118/2007. Proíbe o corte no fornecimento de água e energia elétrica por parte do DAESA e da SAELPA e/ou qualquer empresa terceirizada, no âmbito do Município de Sousa, e adota outras providências. Disponível em <http://www.camarasousa.pb.gov.br/documentos/Leis_Ordin arias/2007/LOMn2118-2007.pdf >. Acesso em: 24 de fevereiro de 2017.

SOUZA, M. B. de; SILVEIRA, R. C. E. da. Gestão de Recursos Hídricos: uma análise do Plano Municipal de Saneamento Básico de Xangri-Lá/RS. Redes, Santa Cruz do Sul, v. 21, n. 2, p. 182-197, 2016.

TRIBUNAL DE CONTAS DO ESTADO DA PARAÍBA. SAGRES (Online). Prefeitura Municipal de Sousa. Receita Orçamentária de Serviços. 2006-2016. Disponível em: <http://sagres.tce.pb.gov.br/receita01.php>. Acesso em: 24 de fevereiro de 2017.

TUNDISI, J. G. Recursos hídricos no futuro: problemas e soluções. Estudos avançados, [S.L], v. 63, n. 22, p. 7-16, 2008.

VARGAS MARCOS, F. La contaminación ambiental como factor determinante de la salud. Rev. Esp. Salud Publica, Madrid, v. 79, n. 2, p. 117-127, 2005.

WOLKMER, M. F. S.; PIMMEL, N. F.. Política Nacional de Recursos Hídricos: governança da água e cidadania ambiental. Revista Sequencia. Florianópolis, n. 67, p. 165198, 2013.

ZABALA, G. I.; GARCIA, M. Historia de la Educación Ambiental desde su discusión y análisis en los congresos internacionales. Revista de Investigación, Caracas , v. 32, n. 63, p. 201-218, 2008. 